\title{
Student Attitudes and Perceptions of an Online Problem-based Learning Case Study in Landscape Management
}

\author{
Ann Marie VanDerZanden ${ }^{1,4}$, David Sandrock ${ }^{2}$, \\ and David Kopsell ${ }^{3}$
}

Additional INDEX wORDs. teaching, problem solving, critical thinking, curriculum

SUMMARY. Horticulture graduates entering the landscape (design, installation, and maintenance) segment of the green industry will be faced with a myriad of complicated decision scenarios. Graduates must be able to integrate their understanding of plant science, environmental and physical site constraints, and the human impact on built and natural landscapes to make complex decisions. The objectives of this project were to develop an online case study for use in landscape management and landscape construction courses, and to determine students' perceptions of using this virtual case study to practice active problem solving in landscape horticulture. After completing a scenario from the online case study, students were asked to complete a 20 -question survey instrument consisting of open- and close-ended questions evaluating the case study. Sixty-nine surveys were returned and useable, for a response rate of $76.6 \%$. Overall student attitudes and perceptions of the online case study were positive. Participants felt comfortable using the web-based format (4.3 of 5), and felt it was an effective way to deliver information (4.1). Furthermore, participants rated their ability to summarize the scenario data as 4.2 and also felt confident in their ability (4.1) to make a landscape management recommendation to the homeowner.

A $s$ the landscape profession grows and becomes more sophisticated, there is an increasing demand for students who can integrate the skills of technical knowledge, practical application, and problem solving (Beidler et al., 2006; Berle, 2007; Kitto et al., 1996; VanDerZanden, 2005). In a recent survey, landscape employers ranked "learning problem-solving strategies" third out of 20 skills that undergraduate horticulture students should possess upon completing their fouryear college horticultural programs (Berle, 2007). Helping students develop the skills necessary to logically work their way through complex landscape management decisions is critical to their future careers and is an important part of their undergraduate education.

Case studies are a factual description of circumstances and events that

\footnotetext{
${ }^{1}$ Associate Professor, Department of Horticulture, Iowa State University, 106 Horticulture Hall, Ames, IA 50011

${ }^{2}$ Assistant Professor, Department of Horticulture, Oregon State University, Corvallis, OR 97331

${ }^{3}$ Assistant Professor, School of Agriculture, University of Wisconsin, Platteville, WI 53818

${ }^{4}$ Corresponding author. E-mail: vanderza@iastate.edu.
}

happened in the past and are intended to elicit discussion and analysis of a particular situation (Naumes and Naumes, 2006). Furthermore, case studies are an example of problembased learning: an instructional approach that emphasizes solving complex problems in rich contexts and developing higher order thinking skills (Savery and Duff, 1995). Casebased instruction has been used in medicine, psychology, sociology, law, and business education since the 1800s (Carter and Unklesbay, 1989; Naumes and Naumes, 2006). Case studies are now commonly included in contemporary horticulture curricula as a mechanism for developing students' problem-solving skills.

Over the past two decades, computers, software, and the Internet have profoundly expanded the multimedia resources available for academic course development and instruction. It is now possible to design, present, and analyze virtual case studies with a variety of components (script, photographs, web page links, audio, and video) via the Internet. Several studies have demonstrated that computerbased instruction is an effective addition to traditional content delivery methods (Collis, 1992; Henry et al., 2004; Liu and Bera, 2005; Niemiec and Walburg, 1992).

Because of the need for horticultural graduates to further develop problem-solving skills, the objectives of this study were to develop a virtual, online, multifaceted case study for use in landscape management and landscape construction courses, and to determine students' perceptions of using a virtual case study to practice active problem solving in landscape horticulture.

\section{Materials and methods}

The online case study. The first iteration of the case study was developed by the instructional technology staff at University of Florida using PHP, a reflective computer programming language used to produce dynamic web pages, to create a framework for the case study. The case study includes six different landscape management scenarios (Fig. 1). The case centers on a clickable landscape map with links to relevant case study artifacts in the form of audio and video files, PDF documents, situational information, images, and Internet links, all listed to the right of the clickable map image (Fig. 1). The artifacts associated with the case study were created using multiple software programs as a means to provide information to students in a variety of formats to assist their learning. As a result of difficulties migrating the case study to a different server location in May 2006, the case study was recreated using Dreamweaver (Adobe Systems, San Jose, CA) in Sept. 2006.

Students at each of the three universities participating in this study completed the swamp white oak (Quercus bicolor) scenario for this research. The assignment entailed the students summarizing the information about the scenario, diagnosing the $\operatorname{problem}(\mathrm{s})$, and making a recommendation to the homeowner on how best to manage the situation.

The SURVeY INSTRUMENT. In consultation with experts at the Iowa State University Center for Statistics and Methodology and the Iowa State University Institutional Review Board, a 20-question survey instrument was developed. Questions were designed to gather information on student attitudes and perceptions of 


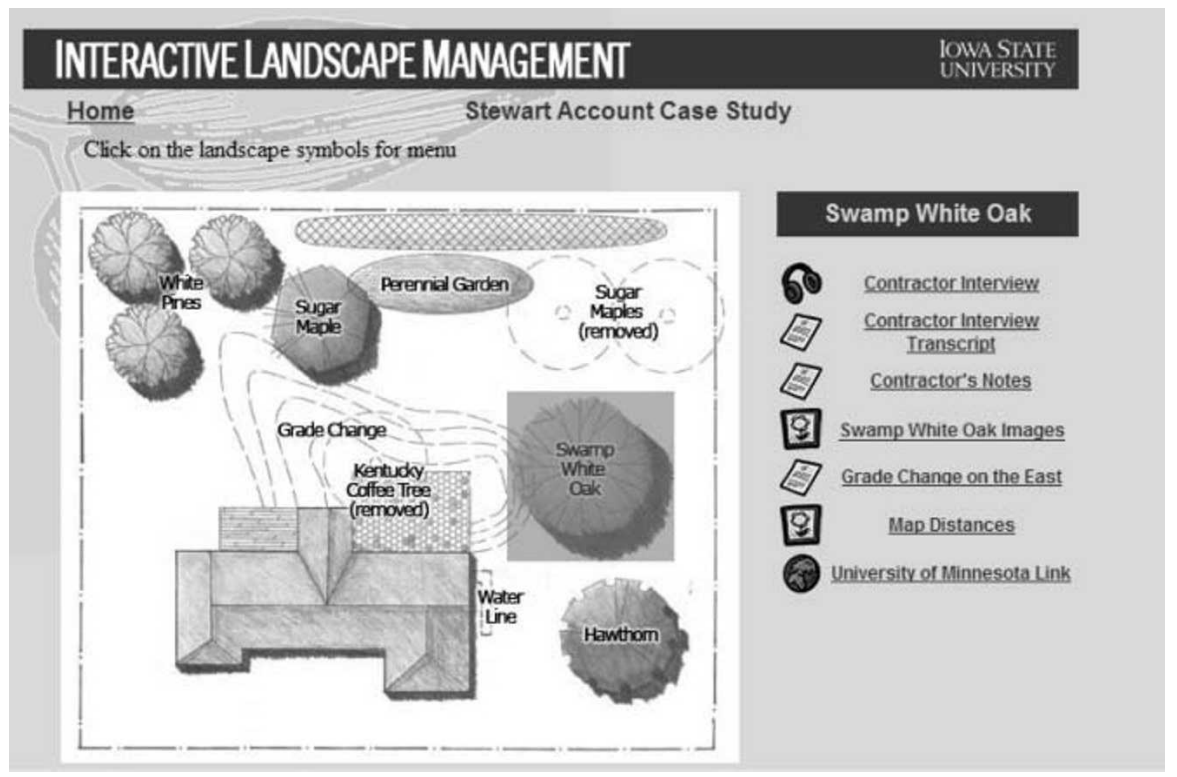

Fig. 1. Interactive landscape management Internet home page with swamp white oak case study scenario highlighted.

the online case study. The questionnaire consisted of 17 closed-ended and three open-ended questions. The closed-end questions were formatted into a five-point Likert-type scale (Likert, 1932) where respondents specified their level of agreement with a statement. The three openended questions asked students to describe: the most effective part of the case study, what they learned from the case study, and what improvements should be made to the case study in the future.

Data were collected from students enrolled in similar landscape construction courses at Iowa State University (ISU), Oregon State University (OSU), and the University of Wisconsin-Platteville (UWP). Data were collected from ISU students in Oct. 2005 (28 students) and Oct. 2006 (23 students), from 24 OSU students in June 2006, and from 15 UWP students in Dec. 2006. In total, 90 students were enrolled in the courses and completed the online case study, and 69 surveys were returned and useable, for a $76.6 \%$ response rate. Data were entered using Excel (Microsoft Corp., Redmond, WA) and were subject to analysis of variance and mean separation using JMP IN (release 5.1; SAS Institute, Cary, NC). Data variances between universities and content-type and technology-type questions were subjected to Barlett's test $(P<0.05)$ for unequal variances.

\section{Results and discussion}

Overall, responses to the 17 close-ended questions were "good" to "very good" (3-4) or in the "neutral" to "agree" (3-4) ranges, depending on how the question was categorized (Table 1). Participants felt comfortable using the web-based format of the case study (question $14 ; 4.3$ of 5 ) and felt it was an effective way to deliver information (question $11 ; 4.1$ ). Participants also agreed with the statement that by using the information provided in the online case study, they were able to summarize the scenario data (question $4 ; 4.2$ ) and ultimately were able to make a recommendation to the homeowner (question 6; 4.1). This comfort level and perceived ability to solve the landscape problem and ultimately make a recommendation to the homeowner suggests that this learning format is a useful way to teach landscape construction and management problem solving to undergraduate students.

Participants rated questions 1 and 2 , respectively, "the amount of information presented in the case study" and "the value of the information presented in the case study to their future career," the lowest, giving each a 3.4. However, it should be noted that a rating of 3 is "good" based on the scale used in this study. The case study did not specifically include content related to future career paths or goals, therefore, students may have not been thinking about the topic or have made the connection to the Internet-based presentation format. Responses to the open-ended question, "what improvements could be made to the case study," showed that participants wanted more scenarios to be included. The fact that students were requesting more information in the case study may reflect their comfort level and how much they were engaged with this learning format.

To compare participant data across universities, equal variances among the data are required. Bartlett's test showed equal variances among responses between universities. Variances between contenttype and technology-type questions were unequal according to Bartlett's test. Therefore, an alternate Welch analysis of variance test was used and this showed that these group means were not significantly different. When each question was compared using Tukey-Kramer HSD at the $\alpha=0.05$ level, three questions exhibited significant differences in the mean participant response across the universities. Responses to question 6, "by using the information provided in this tool I was able to make a recommendation to the homeowners," were different between ISU (3.9) and UWP (4.6), but neither was different from OSU (4.2). Responses to question 15, "more case studies in the web-based format should be included in future horticulture classes," were also different between ISU (3.6) and UWP (4.4), but neither was different from OSU (3.9). Responses to question 7, "I like to learn using case studies," were different between OSU (4.3) and ISU (3.7), but neither was different from UWP (4.2). There were no differences among participant responses to the remaining questions across the universities. Case studies are used minimally in the horticulture curricula at all three universities, particularly in upper division courses. The lowest means for these three questions were reported by students at ISU. This may be in part because for most students, the swamp white oak case study was the first time they had completed a case study with that level of complexity in their undergraduate horticulture curriculum. 
Table 1. Participant responses after completion of the interactive landscape management case study across universities (Iowa State University, OR State University, and University of Wisconsin-Platteville) separated by question type.

\begin{tabular}{|c|c|c|c|}
\hline Question & $\begin{array}{l}\text { Responses }^{\mathrm{z}} \\
\text { (no.) }\end{array}$ & $\begin{array}{c}\text { Response } \\
{[\text { mean } \pm \text { SE }(1-5 \text { scale })]}\end{array}$ & SD \\
\hline \multicolumn{4}{|l|}{ Content-based questions } \\
\hline 1. The amount of information presented in this teaching tool was... & 69 & $3.4 \pm 0.1^{y}$ & 0.9 \\
\hline $\begin{array}{l}\text { 2. The value of the information presented in this teaching tool to } \\
\text { my future career was... }\end{array}$ & 66 & $3.4 \pm 0.1^{y}$ & 0.9 \\
\hline 3. The educational tool as a whole was... & 69 & $3.7 \pm 0.1^{y}$ & 0.8 \\
\hline $\begin{array}{l}\text { 5. By using information provided in this tool I was able to diagnose } \\
\text { the problem with the oak. }\end{array}$ & 68 & $4.0 \pm 0.1^{\mathrm{x}}$ & 0.7 \\
\hline $\begin{array}{l}\text { 6. By using information provided in this tool I was able to make a } \\
\text { recommendation to the homeowners. }\end{array}$ & 69 & $4.1 \pm 0.1^{\mathrm{x}}$ & 0.7 \\
\hline 7. I like to learn using case studies. & 68 & $4.0 \pm 0.1^{x}$ & 0.8 \\
\hline \multicolumn{4}{|c|}{ Technology-based questions } \\
\hline 11. This tool is an effective way to deliver information. & 69 & $4.1 \pm 0.1^{x}$ & 0.7 \\
\hline 12. The interactive format of this tool aided my learning. & 69 & $3.8 \pm 0.1^{\mathrm{x}}$ & 0.8 \\
\hline 13. I prefer this web-based format to a printed format. & 69 & $3.7 \pm 0.1^{x}$ & 1.0 \\
\hline 14. I felt comfortable using this web-based format. & 69 & $4.3 \pm 0.1^{x}$ & 0.8 \\
\hline $\begin{array}{l}\text { 15. More case studies in this web-based format should be included } \\
\text { in future horticulture classes. }\end{array}$ & 69 & $3.8 \pm 0.1^{\mathrm{x}}$ & 0.9 \\
\hline
\end{tabular}

${ }^{\mathrm{z}}$ Total responses, $\mathrm{n}=69$.

${ }^{y} 1$ = poor, 2 fair, $3=$ good, 4 = very good, $5=$ excellent, 6 = blank or unable to rate (a rating of 6 was noted but not averaged in the mean).

${ }^{\mathrm{x}} \mathrm{l}=$ strongly disagree, $2=$ disagree, $3=$ neutral, $4=$ agree, $5=$ strongly agree, $6=$ blank or unable to rate (a rating of 6 was noted but not averaged in the mean).

When the questionnaire responses were grouped according to the type of question, there was no significant difference in participant response between the content-type questions and the technology-type questions $(P \geq 0.169$; Table 1). Thirteen of the 69 participants left the question pertaining to the audio clip blank or "unable to rate." Responses to this question did not distinguish between situations where the audio portion did not work or if the participant was not able to rate its usefulness.

Participant responses to the three open-ended questions were evaluated and categorized into themes for each question. Responses for the three questions were grouped across the three universities (data not shown) and key themes for each question are reported here. When asked, "what was the most effective part of the web-based case study," three topics were listed most frequently: the case-related resources $(55.5 \%)$, the assignment itself (16.6\%), and the organization of the case study (14.8\%). Participants most often listed refining their problem-solving skills (42.6\%) and learning a landscape construction or management technique (29.6\%) as "what they learned from completing the case study." When asked, "what improvements could be made to the case study," the top three responses listed by participants were wanting more resources $(50 \%)$, wanting more and better images $(22.2 \%)$, and wanting the technical problems associated with the case study fixed (18.5\%).

The positive participant response and participant comfort with this online case study, coupled with the ability of participants to successfully summarize case study data and make a recommendation to the homeowner, suggests that this is an effective method for teaching problemsolving skills in landscape horticulture. The organization of the case study and the number and quality of resources available to students were important to their success. Although there was a significant investment of time and money in developing this case study, the framework is now in place to create additional problemsolving scenarios. As a result, additional scenarios currently are in development and will be used in future courses at the three universities. The case study described in this manuscript is being beta-tested using a new software program developed at ISU that allows an instructor to quantify how students are using the case study resources. Course management programs such as WebCT (Blackboard Inc., Washington, DC) and other related software are making it easier and less expensive to create online problem-based learning scenarios for students.

\section{Literature cited}

Beidler, K., J. Iles, S. Nusser, and A.M. Van Der Zanden. 2006. Assessing the preparedness of postsecondary graduates entering the landscape contracting industry. HortTechnology 16(2):312-317.

Berle, D. 2007. Employer preferences in landscape horticulture graduates: Implications for college programs. $\mathrm{N}$. Amer. Colleges Teachers J. 51:21-25.

Carter, K. and R. Unklesbay. 1989. Cases in teaching and law. J. Curriculum Studies 21:527-536.

Collis, B. 1992. Anticipating the impact of multimedia in education: Lessons from the literature. Computers Adult Educ. Training 2:136-149.

Henry, P.H., K. Midden, and E. Lieske. 2004. Comparison of instructional methods for teaching landscape construction 
techniques to undergraduate horticulture students. N. Amer. Colleges Teachers J. 48:8-12.

Kitto, S.L., W.G. Smith, J.T. Sims, A. Morehart, B. Vasilas, and J. Pesek. 1996. Evaluation of the curriculum of a Department of Plant and Soil Sciences. N. Amer. Colleges Teachers J. 40(2):24-31.

Likert, R. 1932. A technique for measurement of attitudes. Arch. Psychol. (Frankf.) 140:5-55.
Liu, M. and S. Bera. 2005. An analysis of cognitive tool use patterns in a hypermedia learning environment. Educ. Technol. Res. Dev. 53(1):521.

Naumes, W. and M. Naumes. 2006. The art and craft of case writing. M.E. Sharpe, Armonk, NY.

Niemiec, R.P. and H. Walburg. 1992. The effects of computers on learning. Int. J. Educ. Res. 17:99-108.
Savery, J.R. and T.M. Duff. 1995. Problem-based learning: An instructional model and its constructivist framework. Educ. Technol. 35:31-38.

Van Der Zanden, A.M. 2005. An integrated approach to enhance critical thinking skills in a landscape construction course. N. Amer. Colleges Teachers J. 49:53-55. 